\title{
Albanian Banking System: Risk Behavior, Bank Capital and their Mutual Relationship with Cost Efficiency
}

Phd Candidate Aida Mosko

\author{
Lecturer, University “Fan S. Noli”, Albania; aida.mosko@yahoo.com
}

Prof. Ass. Dr. Anilda Bozdo

Professor, European University of Tirana, Albania; anildabozdo@gmail.com

\author{
Doi:10.5901/ajis.2015.v4n3p45
}

\section{Abstract}

Albanian financial systems is dominated and identified by banks because its assets account for more than 95 percent of it. At the same time, it has to be mentioned that its role is very important to the stability and soundness economic system. This is the reason that has brought Albanian banking system in the focus of different researches relied on theoretical and empirical literature. Among others they aim to explain the relationship between risk and capital and also the dynamic of bank efficiency of the Albanian banking system. The topic of bank efficiency has been studied either for the whole banking system or for individual banks that are part of it. The relation between risk and capital is found to be positive and simultaneous, while researches on the analyses of cost efficiency show the presence of inefficient banks in Albania but the relationship between ROA or size of the bank with the cost efficiency is not clear. While analyzing the relationship between capital and risk it is very important to take in consideration bank efficiency. The level of bank efficiency is very important to and determines both capital and risk. On the other side, the capital regulation and risk-taking behavior influenced by it has its impact on efficiency. Their impact might give upward or downward movement on efficiency. Relied on theoretical and empirical literature of the interrelationship between risk-taking, capital and efficiency, this paper states hypothesis and introduces a model to test them in case of Albanian banking system.

Keywords: bank capital, risk-taking, cost efficiency

\section{Introduction}

Current Albanian banking system has his roots in 1992 after collapse of the centralized economy. In 1992 Albanian banking system started its operation in two levels. In 2015 there are 16 banks operating in Albania which provide services like: deposits, accounts, transfers, loans, e-banking, etc. in a competitive environment. Banking sector is the main pillar of financial intermediation in Albania. During 2014 assets of banking sector constitute $91.7 \%$ of Gross Domestic Production and 5 banks (out of 16) that dominate this sector account for $68.4 \%$ of system credit portfolio and $73.4 \%$ of deposits. Being such a dominant segment of the financial system, the efficiency on its operation is very important. Banks are a very important service industry that in Albania dominates the financial system. In terms of providing country's financial services, banking system has a monopoly position. The second component of the financial system is still in developing phase. Banking assets constitute for more than 95 percent of the assets of the financial system. They work according to the traditional business model and based on this they ensure simple financial structure and offer plain products and services. Their activity is exercised in a stringent and conservative regulatory environment supervised in a strict way by Bank of Albania. Furthermore, efficient bank operation, which contributes to financial stability, ensures higher-quality services at low costs for enterprises and households. In this context, analyzing the efficiency and the determinant factors it is important for both supervisory authorities and bank management. The first ones are supported on designation of regulatory framework while the second on drawing their business plans. In the frame of European banking industry, the process of financial integration is associated by the debate about the benefits of strengthened competition on credit markets and greater efficiency. Increase of competition in the banking sector forces banks to operate closer to the efficiency production function or in other words, closer to the "best practice". Besides this, competition is also linked with risk-taking. Increased competition reduces the market power, decreases their charter value and so may lead banks to greater risk-taking. Regulators have tried to address this possible incentive of taking higher risks by capital requirements and appropriate supervision. Capital adequacy has taken a leading role in the prudential 
regulatory process.

With regard to these developments, there are a number of studies on the impact that capital, business models and operating efficiency have on bank risk. The recent credit crisis rises up the necessity of analyzing bank risk in the frame of enhanced bank efficiency and lower bank capital. Based on this, it is very important to assess firstly the impact of efficiency on bank risk. It can happen that because of low levels of efficiency, banks have the incentive to improve their performance by neglecting intensive monitoring of credit. On another perspective, changes in bank risks may influence efficiency levels, increases in bank risk can cause a decline in efficiency (cost efficiency) that is related to lower credit screening.

Secondly, it is very important to assess the impact that bank capital has on the relation between risk and efficiency. The level of capital might affect this relation. For instance, because of moral hazard problems banks might increase the incentives of lowering capitalization and undertake more risks that mean higher non-performing loans in the future. In the case of well-capitalized banks moral hazard problems may be lower and they can be both more efficient and prudent than low capitalized ones. In the frame of capital costs, that are higher in case of highly capitalized banks, maximization of revenues through increase of risk-taking level can be considered.

The Albanian financial system is mainly based on the banking sector. Non-bank financial sector is left in shadow and intermediation through it continuous to be weak and unstructured. Based on this and also on the fact that banks in Albania stand in a monopoly sector position, the competition within financial system in Albania is more an intra sectorial than inter sectorial one. Albanian banking system has undergone 20 years of restructure and during this time none of the banks has gone out from the market. The study of bank sector efficiency makes possible to find out what are the reason that this has happened. It is because of system's high efficiency or because it is paid a lot of more attention to protection than efficiency. Studying the relationship between risk-taking, capital levels and efficiency in case of Albanian banking system is very important. While there are studies on the relation capital - risk for the Albanian banking system, to my knowledge, there is no study on the impact that efficiency has to this relation. This papers analysis all possible variables to be used for the estimation of cost efficiency, bank capital and risk-taking.

The objective of this work is to make an overview of literature (theoretical and empirical one) on the impact that efficiency has on capital and risk-taking in the case of Albanian banking system and vice-versa, how is efficiency influenced by changes on risk-taking behavior because of capital regulation. It also aims to determine the variables that are going to be use to the model. Section two gives a overview of related literature firstly on the relation between risk and capital and secondly on the influence that efficiency might have on this relation. The third section makes an analysis of the variables that are going to indicate efficiency, risk-taking and bank capital. Since the theory provides conflicting predictions to this relationship, the only way to examine it for the Albanian banking system is by an empirical analysis. Session three, in the first part of it introduces the main hypotheses for the relationship between risk and capital. In the second part of it discusses the methodology and data and in session 4 concludes.

\section{Related Literature}

Based on the theoretical literature, capital regulation is very important because it controls the risks taken by banks and also their solvency. The protection system of financial safety net may have negative effects on bank risk-taking incentives and for this reason they cannot be considered as an accurate tool of prudential regulation. The most important role, among the different tools used for prudential purposes, has been played by capital adequacy regulations. However, in regard to the optimal design of capital adequacy regulation and its effects to bank risk-taking, theoretical literature gives contradictory results. This means that there is no plain answer on whether higher capital ratios reduce bank's risk taking level. On the other hand, capital adequacy regulation has to be synchronized with other regulatory and market instruments. Market discipline is very important when we come to the point of bank risk-taking and capital strength. If depositors are well informed they will require returns based on the risk taken over by bank. On the other side, banks will hold more capital to keep down insolvency risk. The situation is not the same when these depositors profit from tools of safety net or underestimate systemic risk. If this is the case, the increase on bank risk is not accompanied with the increase on capital hold for solvency risk.

There are many theories on the relation between capital and risk. They use different financial models to evaluate this relation. The option pricing model introduces the idea that equity maximization value is connected with the maximization of the option value of deposit insurance, increase of leverage and of the asset risk. According to this: an increase on deposit liability is not associated with payment of default risk premium; increase of asset risk leads to the increase of managerial effect of this action; increase of leverage (decrease of equity capital) leads to the increase of 
managerial benefit from the increase of asset risk. If bank behaviour tends to increase the deposit insurance the relation between capital and risk is going to be negative, whereas if increasing of risk appetite dominants bank behaviour the relation between risk and capital is positive.

The early empirical literature that examines the effect of bank capital regulations on bank behaviour, Peltzman (1970), Mayne (1972) was focused on the effectiveness of financial regulation and more precisely on the impact that flat rate deposit insurance has on incentives for excessive risk-taking by bankers at the expense of the Federal Deposit Insurance Corporation. Results from these studies show that bank manager's target capital ratios were not affected by the requirements of the banking capital regulation and furthermore they suggest controlling for other factors to limit risktaking.

The introduction of the first Basel Accord (1988) on bank capital, initiated a number of studies on the effects of bank capital regulations. Ediz et al., (1997) find a positive influence of capital adequacy regulation on the increase of capital ratios although there has not been any shift to the riskier assets for their portfolios and off-balance sheet exposures.

Kwan and Eisenbeis (1997) put a link between empirical literature on bank capital regulation and studies related to bank efficiency. Following Hughes and Moon (1995), they emphasized the importance of efficiency when analyzing the relationship between bank capital and risk. They theoretical arguments were followed by studies that find bank risk-taking and moral hazard incentives determined by both efficiency and bank capital. Furthermore, in case of a banking system with different ownership structures, it is important to study if this relationship (capita-risk-efficiency) is influenced by this factor (ownership structure). This is what Goddard et al., (2001), studied for European banking. Jansen and Meckling (1976) suggest that lack of capital market discipline has a negative impact to the owner's control over the management and it gives to the managers the possibility of pursuing their own agenda and neglecting the issue of efficiency.

Altunbas, Carbo, Gardener \& Molyneux (2007), examined in their study the relationship between capital, risk and efficiency in European banking for the period 1992-2000. According to the results of empirical evidence banks with more capital tend to be less efficient and also the ones to take on excessive risk while they didn't find any incentive to take on more risk in case of inefficient European banks. The results show a positive relationship between risk and capital level and the positive influence that financial strength of the corporate sector has in reducing capital levels and bank risktaking. In the case of commercial and saving banks there are no major differences on this relationship while co-operative banks capital levels are inversely related to risks. According to Fiordelisi, Marques-lbanez \& Molyneux (2010) efficiency reduces risk-taking and capital improves efficiency.

All the above literature represents the relationship between bank cost efficiency, capital and risk-taking and we find out that risk-taking is positively affected by bank regulation, capital and deposit insurance. On the other hand, risk is negatively affected by bank size, managerial ownership, capital and loan growth.

\section{Hypotheses, Model and Data}

\subsection{Main hypothesis between capital and risk}

Moral hazard problems coming up from the existence of a financial safety net, agency problems and the effects of regulatory actions are very important when analyzing the relationship between capital and risk. Main hypothesis on the relation between capital, risk and efficiency will be based on the contribution of these factors.

The moral hazard hypothesis that arises in case of agency problems: Based on this hypothesis the relationship between capital and risk is negative. In case of high leverage position, capital decrease will be accompanied by increase on their risk level and that shows a negative relation between risk and capital.

According to Modigliani and Miller theory firm's earning power and the risk of its underlying assets lays down its market value. The basic idea of this theorem is that doesn't make any difference whether investments of a firm are financed with equity of debt. This applies in terms of complete financial markets and perfectly informed depositors about bank's risk to failure. Since the contribution of Modigliani and Miller (1958), researchers have studied how to reach an optimal capital structure by implications of deviations from the frictionless world that they assumed in their theory. Later, Jensen and Meckling (1976) brought the concept of "agency theory". They emphasize the conflict of interest between different contracting parties, principals and agents that are shareholders (owners), managers and equity holders. Since their seminal work, a vast literature can be found on explanations given to the nature of these conflicts of interests and also on the methods to solve them. According to Jansen and Meckling (1976), the agency relationship can be defined as a contract between the principal and the agent. The entire cost of failure on pursuing goals is hold by managers while 
they can have only a fiction of the benefits.

The moral hazard is present in the case of deposit insurance with full cover. This kind of deposit insurance does not reflect the asset risk and in this way banks have the incentives to increase riskiness of their portfolio. Benson et al. (1986) and Kane (1985) has analyzed the way how fixed-rate insurance stimulates risk-taking by banks. Merton (1977) and other authors have studied moral hazard due to deposit insurance. The extreme case of its implication is in zombie banks (Kane 1989).

Gorton and Rosen (1995) argue that managers will tend to take on more risk in periods of an unhealthy banking industry. Better capitalized banks have less moral hazard incentives.

The contribution of regulators and supervisors influences a positive relationship between capital and risk. According to their requirements the increase of bank's risk-taking level has to be followed by the increase of the capital hold to cover these risks. Required additional capital buffer in case of banks with higher level of risks enables them to avoid the costs of issuing equity at short notice.

Bank efficiency level may have an impact on future bank risk. Decline in efficiency will lead to an increase in bank's risk. It supposed to be a negative relationship between risk and efficiency in case of exogenous events. Such events increases problem loans, increases risk and in respond to these banks have to pay additional costs and managerial efforts. According to this point of view increase in bank risk is expected to decline cost efficiency.

Summarizing all above, risk, capital and efficiency are all related and modelling of the relationship between capital and risk need has to include bank efficiency.

\subsection{Methodology and data}

The discussions on efficiency are based on the stochastic efficient frontier production methodology developed by Aigner et al (1997). Cost efficiency can be defined as a measure to evaluate whether bank costs comes from the best practices related to costs, best combination of them selected in the entirety of combinations for production of the same output at the same conditions. Estimation of cost efficiency can be by the use of non-parametric and parametric techniques. Nonparametric techniques in cost efficiency estimation require techniques of linear programming. Meanwhile, based on parametric techniques cost efficiency derives from a cost function wherein variable costs depends on input prices, quantity of output variables, random error and inefficiency. Based on duality theory, in certain conditions (e.g exogenous prices or out of managerial control, and optimal behavior of producer), characteristics of production function (economies of scale or economies of scope) can be indirectly drawn from the use of cost or profit function. Based on Aigner, Lovel and Schmit (1997) and Meeusen and Broeck (1977) cost function of a firm is:

$$
T C_{b}=C\left(Q_{i}, P_{j}, \varepsilon_{b}\right) b=1, \ldots . ., n
$$

Where $C_{b}$ is bank total operational cost, $Q_{i}$ represents the vector of quantity of bank output variables, $P_{j}$ is the vector of prices of bank input variables, $\varepsilon_{b}$ represents the compound random error.

Compound random error term consists of two parts as presented below:

$\varepsilon_{b}=u_{b}+e_{b}$

Where, $u_{b}$ refers to the endogen factors while $e_{b}$ refers to the exogenous factors that influence bank production cost. In this way, term ub shows an increase on bank production cost because of the inefficiency factor which may result from an error in management. As such we can mention the irrational use of the quantity of inputs for given prices. On the other side, the other component of compound random error, $e_{b}$, represents a contemporary increase or decrease on bank costs as the result of random factors that flows from mistakes on data's, on measurement of unexpected or uncontrolled factors. As such we can mention time, strikes, wars and other factors that are not influenced by changes on the methods of management.

To make easy the measurement, $u_{b}$ and $e_{b}$ are supposed to be separable from the other part of the cost function and both sides of the equation (1) can have a logarithmic form:

$\ln T C_{b}=f\left(Q_{i}, P_{j}\right)+\ln u_{b}+\ln e_{b}$

Where $f$, represents the form of cost function and $e_{b}=\ln u_{b}+\operatorname{In} e_{b}$ represents components of the error term. It is the second part of the equation that makes the difference between parametric and non-parametric techniques of efficiency, the how we decompose the error term. Non-parametric approach are based on the assumption that there is no error coefficient and in this way every deviation from the best way of combination of inputs to produce in an efficient way the outputs is considered as part of inefficiency. On the other side, parametric techniques are based on the assumption that inefficiency has an asymmetric design which in most of the cases is half normal while random errors has a symmetric distribution, in most of the cases normal standard. 
Estimation is conducted using a maximum likelihood procedure. The efficiency model is written as follows:

$\ln (T C)=$

$\sum_{i=1}^{2} \alpha_{i} \operatorname{Ln} Q_{i}+\sum_{I=1}^{3} \beta_{I} \ln P_{i}+\frac{1}{2}\left[\sum_{i=1}^{2} \sum_{j=1}^{2} \delta_{i j} \operatorname{Ln} Q_{i} \operatorname{Ln} Q_{j}+\sum_{i=1}^{3} \sum_{j=1}^{3} \lambda_{i j} \operatorname{Ln} P_{i} \operatorname{Ln} P_{j}\right]+\frac{1}{2}\left[\sum_{i=1}^{2} \sum_{j=1}^{2} \delta_{i j} \operatorname{Ln} Q_{i} \operatorname{Ln} Q_{j}+\right.$ $\left.\sum_{i=1}^{3} \sum_{j=1}^{3} \lambda_{i j} \operatorname{Ln} P_{i} \operatorname{Ln} P_{j}\right]+\sum_{i=1}^{3} \sum_{j=1}^{2} \rho_{i j} \operatorname{Ln} P_{i} \operatorname{Ln} Q_{j}+e$

Banks will be considered as multi production firms, 2 outputs and 3 inputs. Input vector is compound by: (1) price of funds $p_{1}$; (2) price of labour, $x_{2}$ and (3) price of physical capital, $x_{3}$. Output vector, based on the assumption that it represents the real portfolio of products and services of banks that operates in Albania, is compounded by: (1) total loans, $\mathrm{q}_{1}$; (2) other earning assets, $\mathrm{q}_{2}$.

This study is based on previous empirical findings that consider bank efficiency as a key component for bank management while investigating the relationship between cost efficiency, risk-taking and bank capital. A system of equations is determined to make possible estimation of their interrelationships. The modeling framework it is based on various approaches suggested by Shrives and Dahl (1992) Kwan and Eisenbeis (1997) and Altunbas et al. (2007). Table 1 presents the empirical model for the three-stage last squares to estimate the relationship between efficiency, capital and risk-taking.

Table 1. Empirical Model of the Three-Stage Least Square (3SLS)

\begin{tabular}{lll}
\hline Depencand Variable & Model & \\
\hline EFFICIENCY (EFF) & EFF $=a_{0}$ ETA $+a_{1}$ LTA $+a_{2}$ LASSET $+a_{3}$ LDR $+a_{4}$ RISK $+a_{5}$ PERSTEX $+a_{6}$ FIXTAS + & Equation (1) \\
& $a_{7}$ CIR $+a_{8}$ EGRW $+a_{9}$ CORRUPT $+a_{10}$ FREE & \\
CAPITAL (ETA) & ETA $=a_{0}$ LTA $+a_{1}$ EFF $+a_{2}$ LASSET $+a_{3}$ RISK $+a_{4}$ OBSA $a_{5}+a_{6}$ CIR $+a_{7}$ FIXTAS $+a_{8}$ & \\
& ROA + $a_{9}$ EGRW $a_{10}$ CORRUPTion (2) \\
RISK-TAKING (LTA) & $\begin{array}{l}\text { LTA }=a_{0} \text { ETA }+a_{1} \text { EFF }+a_{2} \text { LASSET }+a_{3} \text { RISK }+a_{4} \text { ROA }+a_{5} \text { PERSTEX }+a_{6} \text { DEPTA }+ \\
a_{7} \text { OBSA }+a_{8} \text { EGRAW }+a_{9} \text { CORRUPT }+a_{10} \text { FREE }\end{array}$ & \\
\hline
\end{tabular}

Equation 1 in Table 1 employs cost efficiency (EFF) as dependant variable. Table 2 gives explanations on the independent variables that are going to be used for its estimation.

Table 2. Independent variables of capital (ETA)

\begin{tabular}{ll}
\hline Indicator & Description \\
\hline ETA & Equity to total asset \\
LTA & Loan to total asset \\
LASSET & Logarithmic asset size \\
LDR & Loan deposit ratio \\
RISK & Loan losses provision to total loan \\
PERSTEX & Personel exp. to total expenses \\
FIXTAS & Fixed asset to total asset ratio \\
CIR & Cost to income ratio \\
EGRW & Annual economic growth \\
CORRUPT & Corruption index \\
FREE & Economic freedom index \\
\hline
\end{tabular}

Equation 2 in Table 1 employs Bank capital as dependant variable. Table 3 gives explanations on the independent variables that are going to be used for its estimation.

Table 3: Independent variables of capital (ETA)

\begin{tabular}{ll}
\hline Indicator & Description \\
\hline LTA & Loan to total asset \\
EFF & Cost efficiency \\
LASSET & Logaritmimi i aseteve \\
RISK & Loan losses provision to total loan \\
OBSA & Off-balance sheet activities to total asset \\
CIR & Cost to income ratio \\
FIXTAS & Fixed asset to total asset ratio \\
\hline
\end{tabular}




\begin{tabular}{ll}
\hline ROA & Return on asset \\
EGRW & Annual economic growth \\
CORRUPT & Corruption index \\
FREE & Economic freedom index \\
\hline
\end{tabular}

Equation 3 in Table 1 employs Bank risk-taking level as dependant variable. Table 4 gives explanations on the independent variables that are going to be used for its estimation

Table 4: Independent variables of risk-taking (LTA)

\begin{tabular}{ll}
\hline Indikatori & Pershkrimi \\
\hline ETA & Equity to total asset \\
EFF & Cost efficiency \\
LASSET & Logaritmimi i aseteve \\
RISK & Loan losses provision to total loan \\
ROA & Return on asset \\
PERSTEX & Personel exp. to total expenses \\
DEPTA & Deposit to total asset \\
OBSA & Off-balance sheet activities to total asset \\
EGRAW & Annual economic growth \\
CORRUPT & Corruption index \\
FREE & Economic freedom index \\
\hline
\end{tabular}

The Albanian banking sector has undergone many changes that have influenced developments on banking sector per group-bank. Banks are classified in three main groups G1, G2, G3. Criteria's for such classification have been: ownership of bank capital and size of bank assets.

The criterion of capital ownership is used till $2003 \mathrm{yr}$. According to this criterion banks were classified as:
a. Banks with state capital (G1)
b. Banks with common capital (G2)
c. Banks with private capital (G3)

Table 5: Share of financial system segments to GDP (2008-2014)

\begin{tabular}{llccccccc}
\hline Licencing ans Supervisory Authority & Financial system & 2008 & 2009 & 2010 & 2011 & 2012 & 2013 & 2014 \\
\hline Bank of Albania & Banking sector & 76.7 & 77.5 & 80.9 & 84.7 & 89.6 & 90.5 & 91.7 \\
& Non-bank institutions & 1.7 & 2.2 & 2.7 & 2.5 & 2.7 & 2.5 & 2.7 \\
& SLAs and their Unions & 0.7 & 0.8 & 0.8 & 0.7 & 0.8 & 0.8 & 0.8 \\
Albanian Financial Supervisory Authority & Insurance Companies & 1.4 & 1.5 & 1.4 & 1.5 & 1.6 & 1.6 & 1.7 \\
& Pension funds & & 0.01 & 0.01 & 0.01 & 0.02 & 0.03 & 0.04 \\
& Investment funds & & & & & 1.21 & 3.7 & 4.5 \\
Financial intermediation & & 80.5 & 82.01 & 85.81 & 89.41 & 95.93 & 99.13 & 101.44 \\
\hline
\end{tabular}

In 2004 yr. banking sector is totally owned by private stockholders and this changes the criterion used on classifying banks. From this year onwards the structure of banking sector is determined by the size of bank assets. Based on the ratio of bank assets market value by banking sector total value of assets, banks can be part of three main groups:

Banks that own less than $2 \%$ of the total value of banking sector assets (G1-group of small banks)

Banks that own more than $2 \%$ but less than $7 \%$ of total value of banking sector assets (G2 - middle size banks)

Banks that own more than $7 \%$ of total value of banking sector (G3 - group of big banks)

Bank size can be considered as an important factor on the differences on efficiency between banks. To make possible an optimal performance of banks, attendance of scale or scope economies a certain size level is required. Big and small size banks have different place in the market and this influences their performance.

\section{Conclusions}

This paper reviewed theoretical and empirical literature on the efficiency of capital regulation and effects that might have capital regulation on the bank's decision. Based on relevant researches it aims to find out the proper approach and 
dependent variables that is going to be applied for the Albanian banking system. The theoretical literature on bank regulation and bank's decisions on risk-taking and capital structure gives contradicting results. Modelling framework is subject to criticism. Capital requirements were supposed to enhance economic growth. Conclusions on the link between capital requirement and economic growth are part of researches focused on indirect effects of capital regulation, which in turn impacts economic growth.

Theoretical studies are not conclusive on the effect that more stringent capital requirements have on bank efficiency. Capital requirements enhance financial stability and improve bank efficiency by larger capital used as buffer and by lowering moral hazard. There are also arguments that higher capital requirement may enhance excessive risktaking. Most empirical evidences suggest that more stringent capital regulation may lead to lower riskiness of bank assets because it reduces bank's exposure to systemic risk. On the other hand, there are studies that don't find to be strong the link between capital requirement and bank risk.

Banks can respond to higher risk-weighted capital requirements by raising equity, cutting down lending or reducing asset risk. The way how banks choose to respond to capital requirements really matters. Each of these alternatives gives different impact to economy growth. What is the way that banks operating in Albania react to higher risk-weighted capital requirements and impact that the alternative they choose have to the economic growth will be the object of following papers. The theoretical and empirical literature presented in this paper will support their assessments and explanations of regressions that might be found.

\section{References}

Altunbas, Y., Carbo, S., Gardener, E.P.M \& Molineux, P. (2007). Examining the relationship between capita, risk and efficiency in European banking. European Financial Management, 13(1), 49-70.

Bank of Albania, 2006-2015. Supervision Annual reports 2005-2014 [Online] Available: http://www.bankofalbania.org/web/supervision_ report_new_2614_2.php

Bank of Albania, 2013. Regulation "On Capital Adequacy Ratio". [Online] Available: http://www.bankofalbania.org/web/rules_and_ regulations_2799_2.php

Bank of Albania, 2013-2014. Annual Reports [Online] Available: http://www.bankofalbania.org/web/Annual_Report_new_2611_2.php

Bank of Albania, 2015. Regulation "On the Bank's Regulatory Capital" [Online] Available: http://www.bankofalbania.org/web/rules_ and_regulations_2799_2.php

Benston, G., Eisenbeis, R., Horvitz, P., Kane, E., \& Kaufman G. (1986). Perspectives on safe and sound banking: Past, Present, and future. MIT Press, Cambridge 1986.

Bernake, B.S., \& Lown, C.S., (1991). The credit crunch. Brookings Papers on Economic Activity 2, 205-247.

Editz, T., I. \& Perraudin, W., (1998). The impact of capital requirements on U.K bank behaviour'. Reserve bank of New York Policy Review, vol.4 (3) 1998 pp15-22

Fiordelisi, F. \& Marquez-Ibanez, D. and Molyneux, P. (2011). Effciency and risk in European banking. Journal of Banking and Finance, Elsevier, vol. 35(5): 1315-1326

Gambacorta, L., \& Mistrulli, P.E. (2004). Does bank capital affect lending behavior? Journal of Financial Intermediation 13, $436-457$.

Goddard, J., Molyneux, P. And Wilson, J., (2001). European Banking - Efficiency, Technology and Growth. London Wiley, 2001

Gorton, G, \& Rosen, R., (1995). Corporate control, portfolio choice and the decline of banking. Journal of Finance. Vol. 50 (5), 1995 , pp.1377-1420.

Haubrich, J. G., and Wachtel, P. (1993). "Capital Requirements and Shifts in Commercial Bank Portfolios." Federal Reserve Bank of Cleveland Economic Review 29 (third quarter): 2-15.

Huang, R., \& Radnovski, L. (2009). Why Are Canadian Banks More Resilient? IMF Working Paper No. 09/152.

Jensen M.C., \& Meckling, W.H., (1976). Theory of the firm: Managerial behavior, agency costs and ownership structure. Journal of Financial Economics 3 (1976), 305-360

Jimenez, G., Ongena, S., Peydro, J-L., \& Saurina, J. (2012). Credit supply and monetary policy: Identifying the bank balance-sheet channel with loan applications. American Economic Review 102 (5), 2301-2326

Kane, E., (1989). The S\&L insurance crisis: How did it happen? Washington, DC: Urban Institute Press

Kapan, T., \& Minoiu, C. (2013). Balance sheet strength and bank lending during the global financial crisis. IMF Working Paper $13 / 102$.

Keeley, M.C. (1990). Deposit insurance, risk, and market power in banking. American Economic Review 80 (1990) 1183-1200

Kishan, R., \& Opiela, T., (2000). Bank size, bank capital, and bank lending channel. Journal of Money, credit and banking 32(1), 129-141

Koehn, M., \& Santomero A.M., (1980). Regulation of bank capital and portfolio risk. Journal of finance 35 (1980), 1235-1244.

Kwan, S. And Eisenbeir, R., (1997) Bank risk, capitalization and operating efficiency. Journal of Banking and Finance, Vol.12 (2 and 3 ), 1997, pp.117-31

Matten, C. (1996). Managing Bank Capital: capital allocation and performance measurement. (2nd ed.) Chichester: Wiley

Mayne, L. S., (1972). Supervisory influence on bank capital. Journal of Finance, Vol.27 (3), 1972, pp 637-51

Merton, R.C., (1977). An analytic derivation of the cost of deposit insurance loan guarantees. Journal of Banking and Finance 1 (1977), 3-11. 
Miles, D., Yang, J., \& Marcheggiano, G. (2012). Optimal bank capital. The Economic Journal 123, 1-37.

Modigliani, F., \& Merton H.M., (1958). The cost of capital, corporation finance and the theory of investment. The American Economic Review, 261-297.

Peltzman, S., (1070) : Capital investment in commercial banking and its relationship to portfolio regulation. Journal of Political Economy, Vol.78 (1), 1970, pp1-26.

Ross, S.A. (1977): The determination of financial structure: The incentive-signaling approach. Bell Journal of Economics 8 (1997) 23-40.

Santos, J. A.C., (1999). Bank capital and equity investment regulations. Journal of Banking and Finance 23, 1095-1120.

Saunders, A., Strock, E., \& Travlos, N.G. (1990). Ownership structure, deregulation, and bank risk taking. Journal of Finance 45 (1990), 643-654.

Shrives, R.E., \& Dahl, D., (1995). The relationship between risk and capital in commercial banks. Journal of Banking and Finance, Vol. 16 (2), 1992, pp.439-57.

Woo, D., (2003). In search of "capital crunch": Supply factors behind the credit slow down in Japan. Journal of Money, Credit and Banking 35(6), 1019-1038. 